\title{
JUST LABOUR: LOOKING BACK
}

\author{
Norene Pupo \\ Editor-in-Chief, \\ Just Labour: A Canadian Journal of Work and Society \\ and \\ Professor, \\ Department of Sociology, \\ York University \\ Toronto, Ontario, Canada \\ npupo@yorku.ca
}

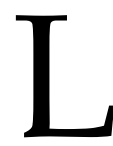

aunching a new volume of Just Labour has always been accompanied by a sense of accomplishment-of reaching out to the labour communities, of opening the door to debate and analysis, and of providing our readers with original papers on a range of labour issues. This Volume certainly evokes a sense of satisfaction with its special section on precarious employment edited by Wayne Lewchuk. But the launch of Volume 22 is also bittersweet. With this volume, we will shutter our windows. While Just Labour will still be available to readers, due to financial pressures, among other constraints, we will not be publishing any new volumes.

Just Labour began as a suggestion during a meeting of the Council of the Centre for Research on Work and Society (CRWS) in 2000. Council members agreed that a periodical of recent research and commentary on labour issues written primarily from a Canadian standpoint would be most welcome amongst labour academics and activists. When we started, our mission was a simple one: develop a publication that speaks to issues confronting Canadian workers and trade unionists, blending academic research, and grounded study with observations and insights gained through on-the-ground experience within the labour movement and the workplace. We invited labour partners, activists and specialists in Work and Labour Studies to submit papers with the hope that lively conversations and debates on the state of work and labour would follow.

The learning curve was steep for the editorial committee. With Just Labour we aimed to fill an important niche, as a Canadian work and labour studies journal. Following our initial launch in 2002, we spent the first few years struggling over the journal's identity with the editorial committee wrestling over our mandate: was it our primary goal to publish a labour-friendly magazine or a journal that would satisfy academic criteria? This was not an easy discussion, as it was important to us that we build bridges uniting those working for justice and 
change on the ground and those charged with educating the next generations of labour activists, organizers, and researchers. In most respects, we feel that we have met our goals.

Over the last 14 years and 22 volumes, there were dozens of people involved in the journal: editorial committee members, authors, reviewers, and editorial assistants. We thank all of you for your time and commitment to this endeavor.

I would like to take this opportunity to name three colleagues who have been most instrumental in producing a first-class and well-rounded publication. Professors Stephanie Ross and Mark Thomas, co-directors of York's Global Labour Research Centre, have worked tirelessly on the last several volumes, while balancing numerous demands related to their directorships and departmental and teaching commitments. It has been my pleasure to work very closely with Mark and Stephanie on this project for the past few years.

Jason Aprile has been Just Labour's Editorial Assistant for many years and it is not an overstatement to say that we would not have been able to operate without him. For your time, commitment, organizational and editorial skills, tech savvy, and patience, we thank you.

Finally, thank you to members of the labour community who supported the principles of Just Labour and helped to build it into an internationally recognized publication. 